\title{
PRIMARY HYPERALDOSTERONISM AS A RARE CAUSE OF HYPOKALEMIA*
}

\author{
Ozge Kurtkulagi, Gulali Aktas, M. Zahid Kocak, Burcin M. Atak, \\ Tuba T. Duman, Satilmis Bilgin, Haluk Savli \\ Abant Izzet Baysal University Hospital, Bolu, Turkey \\ draliaktas@yahoo.com
}

\begin{abstract}
Primary hyperaldosteronism (PHA) is a syndrome characterized by increased aldosterone release and suppressed renin-angiotensin cascade [1]. The main pathophysiological features of the disease are hypertension, alteration in potassium homeostasis, and target tissue damage. The importance of recognizing PHA is due to the fact that it has a very deleterious cardiovascular and renal effect which can result in death [1]. Localization of the source of excessive aldosterone secretion should be investigated following screening and diagnostic
\end{abstract}

procedures in subjects with suspected PHA. Laparoscopic adrenalectomy should be recommended for patients with appropriate surgical candidates with documented unilateral source of aldosterone production [2]. In contrast, bilateral adrenal hyperplasia is best treated medically with antihypertensive drugs containing a mineralocorticoid receptor antagonist.

In this case report, we present a patient with resistant hypokalemia whom consequently diagnosed with PHA and along with the review of the literature.

\section{CASE REPORT}

A 54-year-old female who was scheduled for operation due to congenital hip dislocation was found to have decreased serum potassium in her preoperative tests. Therefore, the patient was referred to the internal medicine outpatient clinic with a serum potassium value of $2.1 \mathrm{mmol} / \mathrm{L}$. The patient was hospitalized for the investigation of underlying etiology and treatment of hypokalemia.

On admission, her systolic and diastolic blood pressures were $150 \mathrm{mmHg}$ and $90 \mathrm{mmHg}$, respectively. Heart rate was 72 per minute, respiratory rate was 16 per minute and body temperature was 36.5 Celsius degree. All of the

* The present case report was carried out as part of investigation work at the Department of Internal Medicine at Abant Izzet Baysal University, Bolu, Turkey. «Primary Hyperaldosteronism as a rare cause of hypokalemia» was written after informed consent of the patient.

Institution, which financed the research: No funds received for the work.

The authors assume responsibility for the published work.

The authors guarantee absence of competing interests and their own financial interest when carrying out the research and writing the article.

The manuscript was received by the editorial staff 24.07.2019. 
other physical examination were within normal range. Her medical history was negative for previous chronic diseases and use of any medications. On electrocardiogram, prominent $\mathrm{U}$ waves were noted. Therefore, potassium replacement was initiated by intravenous route.

The potassium value in spot urine was $12.4 \mathrm{mmol} / \mathrm{L}$. A 24 hour urine collected and urinary potassium excretion in 24 hours of urine was detected as $15 \mathrm{mmol} / \mathrm{L}$, which means transtubular potassium gradient was greater than $4 \mathrm{mmol} / \mathrm{L}$. Since she was hypertensive during clinical follow up in the ward, hypertension along with hypokalemia raised the clini- cal suspicion of hyperaldosteronism. Serum aldosterone renin ratio was measured as $155 \%$. A computerized tomography scan revealed $22 \times 16 \mathrm{~mm}$ neoplasm which was suggestive of adrenal adenoma in the right adrenal gland. Cushing Syndrome was ruled out with a normal cortisol level and pheochromocytoma was ruled out by normal levels of metanephrine in the 24 hours of urine. Spironolactone $50 \mathrm{mg}$ was initiated and serum potassium was raised to normal range. She scheduled for unilateral adrenalectomy and discharged with full recovery of hypokalemia.

\section{DISCUSSION}

PHA is caused by excessive aldosterone release and suppression of the renin-angiotensin cascade. Hypertension, hypokalemia, and damage in target organs (i.e. kidneys, heart) are characteristics of PHA. The prevalence of the disease ranges from $5 \%$ to $12 \%$ in literature [3]. The most common causes of PHA are adrenal adenoma and hyperplasia [3].

The renin-angiotensin-aldosterone system is an important regulator of fluid volume status and blood pressure in human. Renin is secre ted by the juxtaglomerular cells of the kidney in response to a reduction of renal vascular perfusion. Then, renin binds to angiotensinogen and angiotensin 1 which is converted to angiotensin 2 by angiotensin-converting enzyme in vascular endothelial cells. Angiotensin 2 and potassium are the main stimulants of aldosterone secretion. Aldosterone induces the absorption of sodium and the secretion of both potassium and hydrogen ions in the cortical collector channels and in the distal nephron. As a result, volume of extracellular fluid expands and that has a negative feedback on renin secretion. In PHA, aldosterone production is autonomous, resulting in inappropriate expansion of the intravascular volume and development of hypertension [4].

Since PHA has undesired cardiovascular and renal effects which may increase mortality and morbidity, establishing the diagnosis as soon as possible is crucial. Hypertensive patients with hypokalemia (spontaneous or diuretic induced), patients with resistant hypertension (systolic blood pressure $>140 \mathrm{mmHg}$ or diastolic blood pressure $>90 \mathrm{mmHg}$ despite treatment with antihypertensive drugs; prevalence 8-23\%), patients with moderate (SBP/ DBP: $160-179 /$ 100-109 mmHg) or severe (SBP/DBP: < 180/ < $110 \mathrm{mmHg}$ ) hypertension, adrenal incidentaloma together with hypertension, obstructive sleep apnea which is associate with hypertension [5] and hypertension with a family history of PHA [6] should undergo screening for PHA.

Aldosterone-renin ratio is widely accepted as a priority screening test for PHA [4]. However, antihypertensive drugs that run along the renin-angiotensin-aldosterone axis, including beta-blockers, renin inhibitors, angiotensin converting enzyme inhibitors and angiotensin receptor blockers in addition to alpha 2 agonists that have central effects, may affect the results of this test. The ideal test conditions require that these drugs to be discontinued for a period of $\geq 2$ weeks prior to the test [7]. Moreover, mineralocorticoid receptor antagonists (including spironolactone and eplerenone) and potassium-sparing diuretics should be discontinued at least 4 weeks before the test. As hypokalemia also decreases the secretion of aldosterone, it is necessary to normalize the serum potassium level before obtaining blood samples for the test [7].

Patients with suspected PHA by initial screening should undergo additional validation tests to confirm or exclude the diagnosis. However, experts suggest that more confirmatory testing may not be required if spontaneous hypokalemia or plasma renin and plasma al- 
dosterone concentration below detection levels are present (> $20 \mathrm{ng} / \mathrm{dL}$ or $550 \mathrm{pmol} / \mathrm{L}$ ) [8]. These confirmatory tests include the following: oral sodium challenge test, saline infusion test, fludrocortisone suppression test and captopril test.

The priority of diagnostic challenge following the diagnosis is differentiation between unilateral and bilateral aldosterone sources. Since bilateral hyperplasia may not respond to surgery, accurate determination of the underlying subtype is critical for the recommendation of appropriate treatment [5]. Currently, most protocols are based on sectional imaging with computerized tomography and adrenal venous sampling.

PHA treatment aims to prevent morbidity and mortality which are associated with the deleterios effects of hypertension, hypokalemia, and direct aldosterone-related organ damage [7].

The best treatment method for aldosteroneproducing adenoma or unilateral hyperplasia is adrenalectomy, ideally via laparoscopic surgery [7]. After surgery, the aldosterone renin ratio and hypokalemia improve in most patients. In addition most patients (80\% - $95 \%$ ) would have improved blood pressure control. Changes in blood pressure occur mostly during the first 6 months of the postoperative period [4].

Patients with unilateral disease and who are not eligible for surgery should be treated with a mineralcorticoid antagonist [6].

Patients with bilateral hyperplasia do not respond to surgery. Even in bilateral adre- nalectomy, cure rates are less than $20 \%$ [5]. Therefore, clinical practice guidelines recommend that patients with bilateral disease should be treated with additional antihypertensive drugs and mineralacorticoid antagonists, if necessary [9]. Patients should be carefully monitored for electrolyte abnormalities and side effects of mineralacorticoid antagonists. Spironolactone is generally considered to be primary choice. However, eplerenone, is more expensive but selective mineralacorticoid blocker with less antiandrogenic effect, should be chosen in patients who cannot tolerate spironolactone. In addition, amiloride, a drug that blocks the effects of aldosterone in cortical epithelial sodium channels, is another treatment choice [5].

Patients with bilateral disease with resistant hypertension despite appropriate medical treatment, may occasionally benefit from unilateral adrenalectomy, if a subclinical gradient is found in favor of one side in adrenal venous sampling [4].

The PHA is a relatively common cause of secondary hypertension. Patients with PHA have more cardiovascular morbidity and mortality than the patients with essential hypertension. Therefore, proper screening, diagnosis and treatment may positively affect the outcome of many patients. After screening and diagnostic procedures, management algorithms should attempt to lateralize the source of excessive aldosterone secretion.

\section{CONCLUSION}

We suggest that PHA should be kept in mind in differential diagnosis of the patients with hypertension and hypokalemia. We also suggest that surgical treatment (adrenalecto- my) is the treatment of choice in PHA patients with unilateral source of aldosterone production, whereas medical treatment should be chosen in bilateral disease.

\section{REFERENCES}

1. Lee FT, Elaraj D. Surg Clin North Am 2019; 99: 731745. doi: 10.1016/j.suc.2019.04.010.

2. Karagiannis A. Rev Endocr Metab Dis 2011; 12: 15-20. doi: 10.1007/s11154-011-9159-3.

3. Dick SM, Queiroz M, Bernardi BL, et al. Clin Chem Lab Med 2018; 56: 360-372. doi: 10.1515/cclm-2017-0217.

4. Harvey AM. Surg Clin North Am 2014; 94: 643-656. doi: 10.1016/j.suc.2014.02.007.

5. Funder JW, Carey RM, Fardella C, et al. J Clin Endocrinol Metab 2008; 93: 3266-3281. doi: 10.1210/jc.2008-0104.
6. Kline GA, Prebtani APH, Leung AA, et al. Am J Hypertens 2017; 30: 1147-1150. doi: 10.1093/ajh/hpx064.

7. Gyamlani G, Headley CM, Naseer A, et al. Am J Med Sci 2016; 352: 391-398. doi: 10.1016/j.amjms.2016.06.015.

8. Young WF. Clin Endocrinol 2007; 66: 607-618. doi: 10.1111/j.1365-2265.2007.02775.x.

9. Nishikawa T, Omura M, Satoh F, et al. Endocrine $J$ 2011; 58: 711-721. 


\title{
PRIMARY HYPERALDOSTERONISM
}

\section{AS A RARE CAUSE OF HYPOKALEMIA}

Ozge Kurtkulagi, Gulali Aktas, M. Zahid Kocak, Burcin M. Atak,

Tuba T. Duman, Satilmis Bilgin, Haluk Savli

Abant Izzet Baysal University Hospital, Bolu, Turkey

draliaktas@yahoo.com

Primary hyperaldosteronism (PHA) is a syndrome characterized by increased aldosterone release and suppressed renin-angiotensin cascade. Hypertension, alteration in potassium homeostasis, and target tissue damage are characteristic features of the disease. The importance of recognizing PHA is due to the fact that it has a very negative cardiovascular and renal effect which can result in death. In this case report, we present a patient with resistant hypokalemia whom consequently diagnosed with PHA. A 54-year-old female patient who was scheduled for operation due to congenital hip dislocation was found to have decreased serum potassium in her preoperative laboratory tests. Therefore, the patient was referred to the internal medicine outpatient clinic with a serum potassium value of $2.1 \mathrm{mmol} / \mathrm{L}$. Her systolic and diastolic blood pressures were 150 and $90 \mathrm{mmHg}$, respectively. On electrocardiogram, prominent U waves were noted. Therefore, potassium replacement was initiated at once by intravenous route. The potassium value in spot urine was $12.4 \mathrm{mmol} / \mathrm{L}$. A $24 \mathrm{hour}$ urine collected and urinary potassium excretion in 24 hours of urine was detected as $15 \mathrm{mmol} / \mathrm{L}$, which means transtubular potassium gradient was greater than $4 \mathrm{mmol} / \mathrm{L}$. Since she was hypertensive during clinical follow up in the ward, hypertension along with hypokalemia raised the clinical suspicion of hyperaldosteronism. Serum aldosterone renin ratio was measured as $155 \%$. A computerized tomography scan revealed $(22 \times 16 \mathrm{~mm})$ neoplasm which was suggestive of adrenal adenoma in the right adrenal gland. Cushing Syndrome was ruled out with a normal cortisol level and pheochromocytoma was ruled out by normal levels of metanephrine in the 24 hours of urine. Spironolactone $50 \mathrm{mg}$ was initiated and serum potassium was raised to normal range. She scheduled for unilateral adrenalectomy and discharged with full recovery of hypokalemia. Since PHA has undesired cardiovascular and renal effects which may increase mortality and morbidity, establishing the diagnosis as soon as possible is crucial. Hypertensive patients with hypokalemia or adrenal incidentaloma or obstructive sleep apnea syndrome, resistant hypertensive subjects, patients with moderate or severe hypertension, and hypertensive patients with a family history of PHA should undergo screening for PHA. In conclusion, we suggest that PHA should be kept in mind in differential diagnosis of the patients with hypertension and hypokalemia.

Key words: hypokalemia, primary hyperaldosteronism, secondary hypertension.

\section{ПЕРВИЧНЫЙ ГИПЕРАЛЬДОСТЕРОНИЗМ КАК РЕДКАЯ ПРИЧИНА ГИПОКАЛИЕМИИ}

\author{
Озге Курткулаги, Гулали Актас, М. Захид Коцак, Бурчин М. Атак, \\ Туба Т. Думан, Сатилмис Билгин, Халук Савли \\ Университетская больница ил. Абанта Иззета Байсала, г. Болу, Туриия \\ draliaktas@yahoo.com
}

Первичный гиперальдостеронизм представляет собой синдром, характеризующийся повышенным высвобождением альдостерона и подавленным ренин-ангиотензиновым каскадом. Гипертония, изменение гомеостаза калия и повреждение тканей-мишеней являются характерными признаками заболевания. Важность распознавания первичного гиперальдостеронизма обусловлена тем, что он имеет негативное влияние на сердечно-сосудистую систему и почки, которое может привести к смерти. В данном клиническом случае случае мы представляем пациента с резистентной гипокалиемией, у которого впоследствии был диагностирован первичный гиперальдостеронизм. У 54-летней пациентки было запланировано оперативное лечение по поводу врожденного вывиха бедра, было выявлено снижение уровня калия в сыворотке крови в предоперационных лабораторных тестах. Пациентка была направлена в поликлинику внутренних болезней с калием в сыворотке крови 2,1 ммоль/л. Ее систолическое и диастолическое артериальное давление составляли 150 и 90 мм рт.ст. соответственно. На электрокардиограмме были отмечены заметные волны U. Поэтому замещение калия было начато сразу внутривенно. Содержание калия в моче составило 12,4 ммоль/л. 24-часовая собранная моча и экскреция калия с мочой через 24 часа были определены как 15 ммоль/л, что означает, что транстубулярный градиент калия был больше 4 ммоль/л. Так как у нее была гипертоническая болезнь во время клинического наблюдения в палате, гипертония наряду с гипокалиемией повысила клиническое подозрение на гиперальдостеронизм. Отношение альдостерон-ренин в сыворотке крови составило 155 \%. Компьютерная томография показала опухоль $(22 \times 16$ мм), что свидетельствует об аденоме надпочечников. Синдром Кушинга был исключен с нормальным уровнем кортизола, а фреохромоцитома была исключена нормальными уровнями метанефрина в течение 24 часов. Спиронолактон был введен в дозе 50 мг, а уровень калия в сыворотке был повышен до нормального уровня. Ей была назначена односторонняя адреналэктомия, пациентка выписана с полным восстановлением гипокалиемии. Поскольку первичный гиперальдостеронизм имеет нежелательные сердечно-сосудистые и почечные әффекты, которые могут увеличить смертность и заболеваемость, крайне важно установить диагноз 
как можно скорее. Пациентам с гипертонической болезнью, с гипокалиемией или инциденталомой надпочечников, синдромом обструктивного апноэ во сне, пациентам с резистентной гипертонией, пациентам с умеренной или тяжелой артериальной гипертензией и пациентам с гипертонической болезнью в семейным анамнезом следует пройти обследование на первичный гиперальдостеронизм. В заключение мы предлагаем учитывать первичный гиперальдостеронизм при дифрференциальной диагностике пациентов с гипертонией и гипокалиемией.

К л ючевые слова: гипокалиемия, первичный гиперальдостеронизм, вторичная гипертония.

\section{ПЕРВИННИЙ ГІПЕРАЛЬДОСТЕРОНІЗМ ЯК РІДКІСНА ПРИЧИНА ГІПОКАЛІЕМІЇ}

Озге Курткулаги, Гулалі Актас, М. Захід Кочак, Бурчин М. Атак,

Туба Т. Думан, Сатільміс Білгін, Халюк Савлі

Університетська лікарня ім. Абанта Іззета Байсала, м. Болу, Туреччина

draliaktas@yahoo.com

Первинний гіперальдостеронізм являе собою синдром, який характеризується підвищеним вивільненням альдостерону і пригніченим ренінангіотензиновим каскадом. Гіпертонія, зміна гомеостазу калію і пошкодження тканин-мішеней е характерними ознаками захворювання. Важливість розпізнавання первинного гіперальдостеронізму обумовлена тим, що він має негативний серцево-судинний і нирковий вплив, які можуть привести до смерті. У цьому випадку ми представляемо пацієнтку із резистентною гипокаліємією, у якої згодом був діагностований первинний гіперальдостеронізм. У 54-річної пацієнтки, якій була назначена операція через вроджений вивих стегна, було виявлено зниження рівня калію в сироватці крові в передопераційних лабораторних тестах. Пацієнтка була направлена в поліклініку внутрішніх хвороб на той момент калій в сироватці крові дорівнював 2,1 ммоль/л. Ї̈̈ систолічний та діастолічний артеріальний тиск становили 150 і 90 мм рт.ст. відповідно. На електрокардіограмі були відзначені помітні хвилі U. Тому заміщення калію було розпочато одразу внутрішньовенно. Вміст калію в сечі склало 12,4 ммоль/л. 24-годинна зібрана сеча і екскреція калію з сечею через 24 години були визначені як 15 ммоль/л, що означає, що транстубулярний градієнт калію був більше 4 ммоль/л. Так як пацієнтка мала гіпертонічне захворювання під час клінічного спостереження в палаті, гіпертонія поряд з гіпокаліємією підвищила клінічну підозру на гіперальдостеронізм. Співвідношення альдостерон-ренін в сироватці крові склало 155 \%. Комп'ютерна томоградрія показала пухлину $(22 \times 16$ мм), що свідчить про аденому наднирників. Синдром Кушинга був виключений через нормальний рівень кортизолу, а феохромоцитома була виключена через нормальні рівні метанедрину. Спіронолактон був введений в дозі 50 мг, а рівень калію в сироватці був підвищений до нормального рівня. Їй було призначено одностороння адреналектомія, паціентка виписана 3 повним відновленням гіпокаліемії. Оскільки первинний гіперальдостеронізм має небажані серцево-судинні і ниркові ефректи, які можуть збільшити смертність і захворюваність, вкрай важливо встановити діагноз якомога швидше. Паціентам з гіпертонічною хворобою з гіпокаліємією або інціденталомой наднирників, або синдромом обструктивного апное уві сні, пацієнтам з резистентної гіпертонією, пацієнтам з помірною або тяжкою артеріальною гіпертензією і паціентам з гіпертонічною хворобою з сімейним анамнезом слід пройти обстеження на первинний гіперальдостеронізм. На закінчення ми пропонуємо враховувати первинний гіперальдостеронізм при диференціальної діагностики пацієнтів з гіпертонією і гіпокаліеміею.

К л юч в і с лов а : гіпокаліемія, первинний гіперальдостеронізм, вторинна гіпертонія. 